\title{
A new species of Metacyclops Kiefer, 1927 (Copepoda, Cyclopidae, Cyclopinae) from the Chihuahuan desert, northern Mexico
}

\author{
Nancy F. Mercado-Salas ${ }^{1, \dagger}$, Eduardo Suárez-Morales ${ }^{1, \neq}$, \\ Alejandro M. Maeda-Martínez ${ }^{2, \S}$, Marcelo Silva-Briano ${ }^{3,1}$
}

I El Colegio de la Frontera Sur (ECOSUR) Unidad Chetumal, A. P. 424. Chetumal, Quintana Roo 77014, Mexico 2 Centro de Investigaciones Biológicas del Noreste, S. C., Instituto Politécnico Nacional 195, Playa Palo de Santa Rita Sur, La Paz, Baja California Sur, 23060, Mexico 3 Universidad Autónoma de Aguascalientes, Aguascalientes 20100, México

† urn:lsid:zoobank.org:author:313DE1B6-7560-48F3-ADCC-83AE389C3FBD

† urn:lsid:zoobank.org:author:BACE9404-8216-40DF-BD9F-77FEB948103E

§ urn:lsid:zoobank.org:author:A201B2CC-9BAD-4946-8EF1-94A2EC66CA3E

| urn:lsid:zoobank.org:author:5FA43C7B-7B82-453D-A3FD-116FA250A7FF

Corresponding author: Nancy F. Mercado-Salas (nmercado@ecosur.mx)

Academic editor: D. Defaye | Received 19 November 2012 | Accepted 26 March 2013 | Published 11 April 2013

urn:lsid:zoobank.org:pub:EC4EC040-2D68-4117-8679-8BB47C0831C7

Citation: Mercado-Salas NF, Suárez-Morales E, Maeda-Martínez AM, Silva-Briano M (2013) A new species of Metacyclops Kiefer, 1927 (Copepoda, Cyclopidae, Cyclopinae) from the Chihuahuan desert, northern Mexico. ZooKeys 287: 1-18. doi: 10.3897/zookeys.287.4358

\begin{abstract}
A new species of the freshwater cyclopoid copepod genus Metacyclops Kiefer, 1927 is described from a single pond in northern Mexico, within the binational area known as the Chihuahuan Desert. This species belongs to a group of Metacyclops species with a 3443 spine formula of swimming legs. It is morphologically similar to Metacyclops lusitanus Lindberg, 1961 but differs from this and other congeners by having a unique combination of characters, including a caudal rami length/width proportion of 3.5-3.8, a innermost terminal seta slightly longer than the outermost terminal seta, intercoxal sclerites of legs 1-4 naked, a strong apical spine of the second endopodal segment of leg 1 and one row of 6-8 small spinules at the insertion of this spine. The finding of this species represents also the first record of the genus in Mexico and the third in North America, where only two other species, M. gracilis (Lilljeborg, 1853) and M. cushae Reid, 1991 have been hitherto reported. This is also the first continental record of a species of Metacyclops from an arid environment in the Americas. This species appears to be endemic to the Chihuahuan Desert, thus emphasizing the high endemicity of this area.
\end{abstract}

Copyright Nancy F. Mercado-Salas et al. This is an open access article distributed under the terms of the Creative Commons Attribution License 3.0 (CC-BY), which permits unrestricted use, distribution, and reproduction in any medium, provided the original author and source are credited. 


\section{Keywords}

Arid environments, Cyclopoida, freshwater zooplankton, inland water crustaceans, copepod taxonomy

\section{Introduction}

The freshwater copepod genus Metacyclops Kiefer, 1927 was revised by Herbst (1988), who recognized 47 species. Many species have been added from investigations in different regions of the world (Brancelj 1987, Reid 1987, 1991, Herbst 1990, Rocha 1994, Galassi and Pesce 1994, Pesce et al. 1996, Karanovic 2004a) and the genus is currently known to contain more than 62 nominal species and subspecies (Dussart and Defaye 2006). In the Americas, the genus is represented by 24 species, most of them occurring in Central and South America; it appears to be quite less diverse in North America, where only two species have been recorded: Metacyclops gracilis (Lilljeborg, 1853) from Minnesota (Herrick 1895), Maryland (Wilson 1932), and a cave in Texas (Davis 1979), and M. cushae Reid, 1991 (Reid 1991) from a temporary pool in New Orleans Parish, Louisiana. It is probable that the diversity of the genus in North America could be underestimated as result of inadequate sampling of suitable nonplanktonic habitats and because of the exclusion of the genus from regional keys (Reid 1991, Dussart and Defaye 2006, Gaviria and Aranguren 2007, J. Reid pers. comm.).

Lindberg (1961) separated the genus into two distinct groups: 1) the "minutusplanus" group with one spine on the third endopodal segment of the fourth leg and 2) the "gracilis-mendocinus" group with two such spines. Recent taxonomic works (Herbst 1988, Reid 1987, 1991, Fiers 2001, Karanovic 2004a, 2004b) recognize four groups based on the spine formula of the terminal exopodite segment of legs 1-4 (designated as spine formula of legs 1-4). The first group, with a 3443 spine formula contains 52 of the 62 species of the genus. The second (3442) and third (3433) groups each contain one species, M. mortoni Pesce, De Laurentiis and Humphreys, 1996 and M. cushae Reid, 1991, respectively. The fourth group among the species of Metacyclops is the trispinosus-group, with a 3333 spine formula (Karanovic, 2004a, 2004 b). Karanovic (2004b) stated that the trispinosus-group is an easily recognizable group of species with an Eastern Gondwana connection (Africa, India, Australia, and New Zealand). Until recently, it contained 8 species but Karanovic et al. (2011) reallocated six of them in the new genus Pescecyclops (Pescecyclops pilbaricus [Karanovic, 2004], P. laurentiisae [Karanovic, 2004], P. pilanus [Karanovic, 2004], P. arnaudi [G. O. Sars, 1908], P. monacanthus [Kiefer, 1928] and $P$. kimberlyi [Karanovic, 2004] ), distinguished by the presence of three spines on the distal exopodal segment of all swimming legs, only one apical spine on the fourth leg endopod, and the absence of sexual dimorphism. Thus, Metacyclops trispinosus Dumont, 1981 and M. margaretae (Lindberg, 1938) are the only two species of the trispinosus-group that were retained in the genus Metacyclops.

Karanovic (2004a, 2004b) stated that many morphological features in Metacyclops have an extreme range of variation, which raises the question as to its monophyly and taxonomic validity. It is highly possible that a more detailed examination of the fifth 
leg, along with many other currently neglected characters will result in splitting the genus Metacyclops into several different genera. The recent work by Karanovic et al. (2011) included a cladistic analysis and a taxonomic revision of the Australian species. These authors formally recognized the "Metacyclops complex" and provided evidence to state that Metacyclops s. str. is polyphyletic in nature and that some species (like $M$. cushae) are closer to other genus than they are to Metacyclops.

Most of the surveys on the Mexican cyclopoid copepod fauna have dealt with the central and southern regions (Suárez-Morales and Reid 1998, Suárez-Morales et al. 2002). Recent research efforts in arid and semi-arid regions of Central and Northern Mexico (Dodson and Silva-Briano 1996, Mercado-Salas et al. 2006, 2009, SuárezMorales and Walsh 2009; Mercado-Salas and Suárez-Morales 2009, 2011) indicate that the copepod fauna of these habitats is more diverse than previously thought and that it deserves further study. During a recent revision of zooplankton collections from arid areas of Northern Mexico, several specimens of cyclopoid copepods were identified as representing an undescribed species of Metacyclops. The significance of this finding is discussed in terms of currently known diversity and distributional patterns of the genus in the Americas.

\section{Methods}

During the development of a project to estimate the diversity of cyclopoid copepods in arid and semi-arid regions of Mexico, zooplankton samples were collected between 1981 and 2009 in more than 500 water bodies from six states of Central and Northern Mexico (Aguascalientes, Chihuahua, Coahuila, Durango, San Luis Potosí, and Zacatecas). Samples were collected using a conical standard plankton net $(250 \mathrm{~mm}$ diameter and $50 \mu \mathrm{m}$-mesh size) hauled near the shoreline of water bodies. The biological material was then fixed and preserved in $4 \%$ formalin solution. Copepods were sorted out from the original samples and then transferred to $70 \%$ ethanol with a drop of glycerine for long term preservation. Several female and male specimens of a cyclopoid copepod were collected from Coahuila in northern Mexico. These copepods were tentatively identified as Apocyclops panamensis (March, 1913). A second, closer examination of these specimens was performed in the laboratory and differences with respect to $A$. panamensis motivated a deeper analysis which revealed these specimens as members of Metacyclops. The taxonomically relevant characters of this genus were evaluated following Reid (1987, 1991), Herbst (1988), Rocha (1994), Karanovic (2004a, 2004b), and Karanovic et al. (2011). Specimens were processed for taxonomical examination following Reid and Williamson (2010). Three females were dissected and 10 females were prepared for SEM examination with a JEOL LV 5900 microscope at facilities of the Universidad Autónoma de Aguascalientes, Mexico. The SEM processing included dehydration in progressively higher ethanol concentrations (60, 70, 80, 96, 100\%), drying, and gold coating following standard methods. All dissected specimens were mounted in semi-permanent slides with glycerine sealed with Entellan ${ }^{\circ}$, a commercial, 
fast drying mounting medium and sealant. Scaled illustrations were done at 100X magnifications with a drawing tube mounted on a standard Olympus CX31 microscope. Type specimens were deposited in the collection of zooplankton held at El Colegio de la Frontera Sur, in Chetumal, Mexico (ECO-CH-Z) and in the Laboratorio de Ecología of the Universidad Autónoma de Aguascalientes, Mexico.

\section{Results}

Order Cyclopoida Rafinesque, 1815

Family Cyclopidae Rafinesque, 1815

Subfamily Cyclopinae Rafinesque, 1815

Genus Metacyclops Kiefer, 1927

\section{Metacyclops deserticus Mercado-Salas \& Suárez-Morales, sp. n.}

urn:lsid:zoobank.org:act:440E0C58-17CB-4A7F-A841-DC46403F02AB

http://species-id.net/wiki/Metacyclops_deserticus

Figures 1-5

Material examined. Holotype. Adult $q$, specimen dissected, mounted in glycerin sealed with Entellan (ECO-CH-Z-08585). Allotype. Adult $\widehat{\partial}$, dissected and mounted in glycerin and sealed with Entellan (ECO-CH-Z-08586). Paratypes.15 adult $q$ 우 specimens, undissected, ethanol-preserved, vial (ECO-CH-Z-08587). Original plankton samples containing several additional specimens, and the SEM-processed specimens are deposited in the collection of M. Silva-Briano, Laboratorio de Ecología of the Universidad Autónoma de Aguascalientes, Mexico. Samples from the type locality were collected by Alejandro Maeda-Martínez in October 10, 1981.

Type locality. Ephemeral pond at El Refugio bridge, Cerro Bola, Km 70, east of Torreón city, federal highway 40 , Coahuila $\left(25^{\circ} 35^{\prime} 02^{\prime \prime N}, 102^{\circ} 45^{\prime} 02^{\prime \prime W}\right)$. This pond is located in a desertic plain in the southwest margin of the ancient Laguna de Mayrán, a system which is part of the endorheic drainage of the Nazas and Parras rivers. The altitude of the type locality is about 1,100 meters above sea level and the average annual precipitation in the area is $200 \mathrm{~mm}$. At the moment of sampling the surface area of the pond was about 55 meters long and 25 meters wide, the water had an average depth of $50 \mathrm{~cm}$ and $80 \mathrm{~cm}$ at its deepest point.

Etymology. The specific epithet makes reference to the arid habitat from which this species was collected. It was used to emphasize that it is the first American record from arid conditions.

Descriptions. Female: Habitus as in Fig. 1A (dorsal view) and Fig. 4A (lateral view). Length of holotype $0.87 \mathrm{~mm}$ from anterior end of cephalothorax to posterior margin of caudal rami (range $=0.72-0.87 \mathrm{~mm}$; mean $=0.80 \mathrm{~mm} ; \mathrm{n}=9$ ). Body robust, cephalothorax relatively long, slightly expanded laterally at midlength of cephalosome in dorsal view; lateral margins of pedigers 3 and 4 straight, produced posteriorly. 


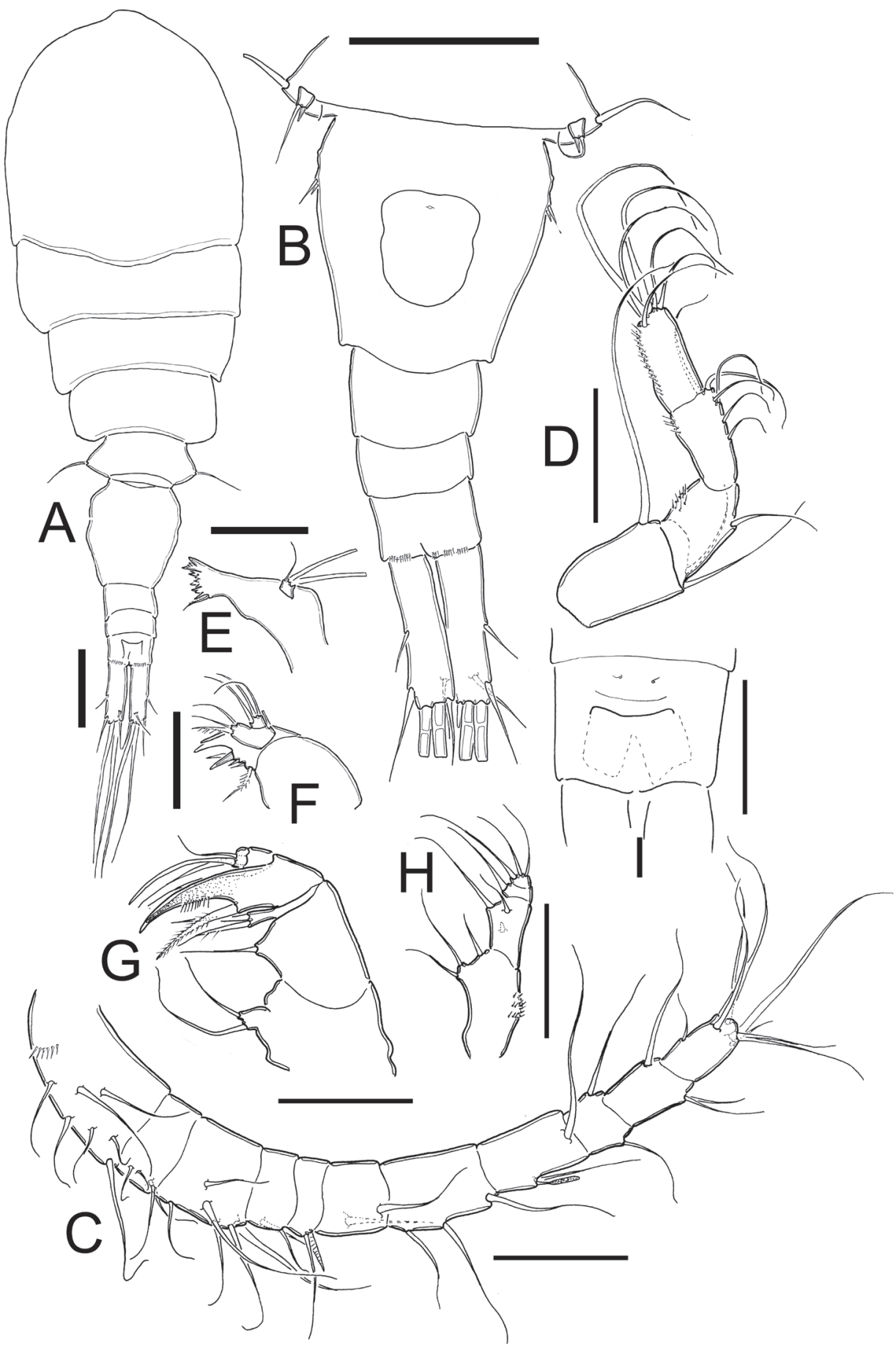

Figure I. Metacyclops deserticus sp. n., female holotype from Coahuila, Mexico. A habitus, dorsal view $\mathbf{B}$ urosome, ventral view $\mathbf{C}$ antennule $\mathbf{D}$ antenna $\mathbf{E}$ mandible $\mathbf{F}$ maxillule $\mathbf{G}$ maxilla $\mathbf{H}$ maxilliped $\mathbf{I}$ anal operculum. Scales bars $\mathbf{A}-\mathbf{B}=100 \mu \mathrm{m} ; \mathbf{C}-\mathbf{I}=50 \mu \mathrm{m}$. 
Cephalothorax length $=0.55 \mathrm{~mm}$, representing $63 \%$ of total body length. Dorsal surface smooth, antennules not reaching distal margin of first pediger. Urosome (excluding caudal ramus) (Fig. 1B) representing 37\% of body. Posterior margins of genital double-somite, free urosomites, and anal somite smooth both dorsally and ventrally. Relative length of each urosomite (proximal to distal) as: 65.4: 10.3: 10.3: 14.1=100. Genital double-somite (Fig. 5E) representing 17\% of body length (excluding caudal rami), somite about 1.1 times longer than broad, with maximum width at proximal half; ventral and dorsal surfaces smooth. Anterior half of genital double-somite expanded laterally. Seminal receptacle with a reduced and narrow anterior part, posterior part rounded and expanding along the somite. Anal somite with distal rows of spines at insertion points of each caudal rami on ventral and dorsal margins. Anal operculum (Fig. 1I) slightly rounded and smooth.

Caudal ramus (Fig. 1B, 5F): Ramus representing 8.2\% of total body length and 0.3 times as long as urosome. Length/width ratio=3.5-3.8. Inner and outer margins smooth. Lateral caudal seta (II) inserted at $53 \%$ of total length of caudal rami. Outermost terminal seta (III) without ornamentation at point of insertion and 0.6-0.7 times as long as caudal ramus. Dorsal seta (VII) relatively short, 0.4-0.5 times as long as caudal ramus. Innermost terminal seta (VI) about 0.5 times as long as caudal ramus. Innermost terminal seta (VI) about $0.8-0.84$ times outermost terminal seta (III). All terminal caudal setae plumose.

Antennule (Fig. 1C, 4A): 11-segmented in all specimens examined, armature per segment as follows (s=seta, $\mathrm{sp}=$ spine, ae=aesthetasc): 1(7s), 2(4s), 3(6s), 4(2s), 5(1s $+1 \mathrm{sp}), 6(2 \mathrm{~s}), 7(3 \mathrm{~s}), 8(2 \mathrm{~s}+1 \mathrm{ae}), 9(2 \mathrm{~s}), 10(3 \mathrm{~s}), 11(7 \mathrm{~s})$. Antennule not reaching posterior margin of first thoracic somite.

Antenna (Fig. 1D, 4C): Four-segmented, basis without cuticular ornamentation, armed with long exopodal seta and two basipodal setae of different size, outer seta 1.6 times longer than inner seta. First endopodal segment with single outer seta and inner group of spinules. Second segment with 6 setae; inner margin with longitudinal row of spinules. Third endopodal segment with 6 terminal setae; inner margin with row of spinules.

Mandible (Fig. 1E): Gnathobase with 7 strongly chitinized teeth and dorsal seta armed with inner row of spinules. Palp reduced, with 2 long and 1 short setae, the later not reaching half-length of former two.

Maxillule (Fig. 1F): Precoxal arthrite with 3 strong chitinized claws and 2 spiniform setae on frontal side. Palp 2-segmented, proximal segment armed with 3 inner setae and outer exopodal seta. Distal segment of palp armed with 3 setae.

Maxilla (Fig. 1G): Precoxa and coxa not fused; precoxal endite armed with two strong biserially setulated setae. Coxal surface naked, proximal endite well developed, with two subequal apical setae. Claw-like distal endite well developed, with row of 6 spinules and basal seta. Endopodite 2-segmented, proximal segment with 2 robust setae, distal segment with single seta.

Maxilliped (Figs. 1H, 4D): Four- segmented. Syncoxa with 3 spiniform setae along inner margin: proximal one without ornamentation at insertion, middle one 


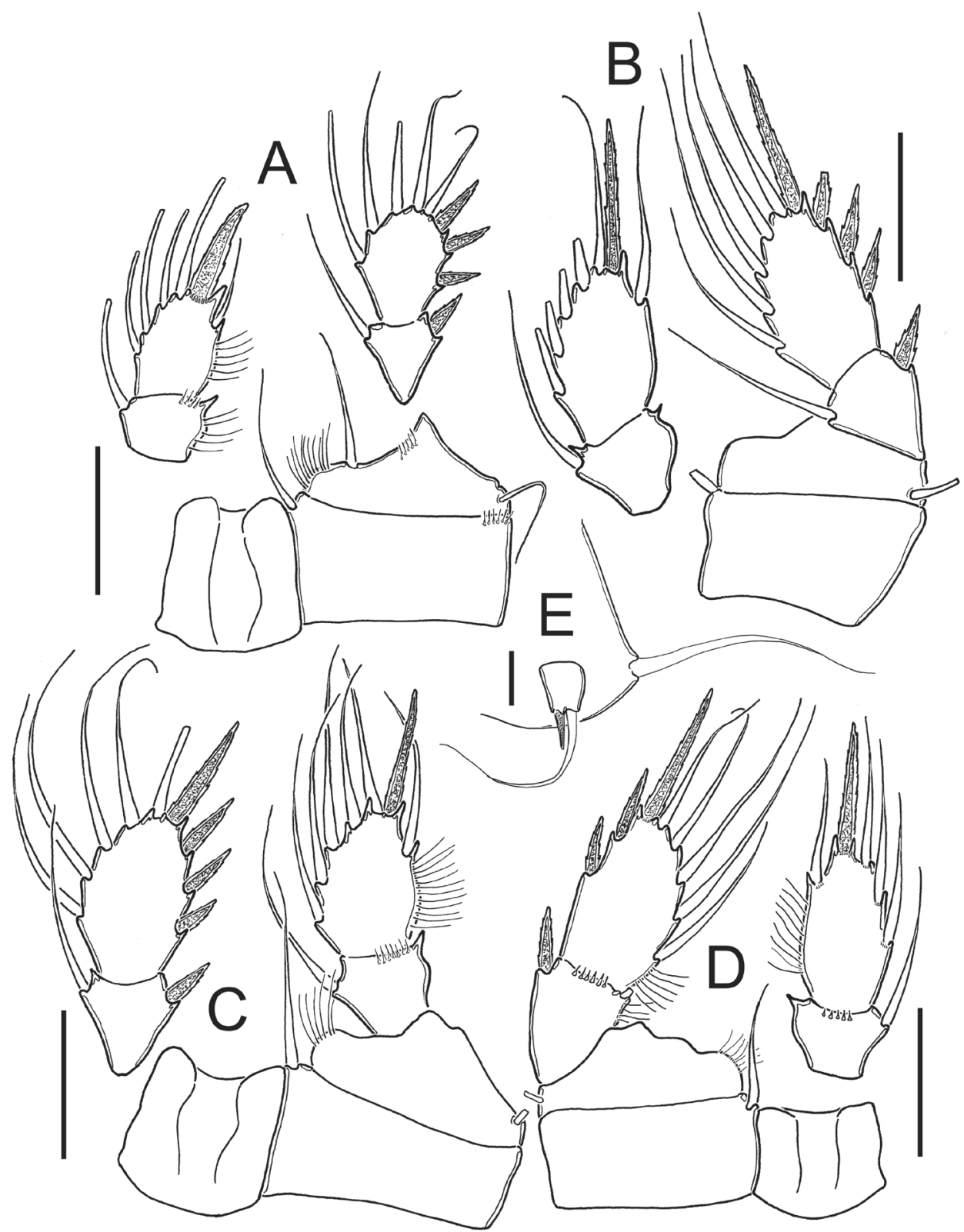

Figure 2. Metacyclops deserticus sp. n., female holotype from Coahuila, Mexico. A Leg 1 B Leg 2 C Leg 3 D Leg 4 E Leg 5. Scales bars A-D $=50 \mu \mathrm{m} ; \mathbf{E}=10 \mu \mathrm{m}$.

longest, more than twice as long as the other setae. Basis with 2 spiniform setae and transverse row of spines. Endopod reduced, 2-segmented, first segment with single lightly spinulate seta. Second endopodal segment armed with spiniform proximal seta and 2 slender setae. 
Legs P1-P4: with naked intercoxal sclerites, distal margins with rounded projections. All endopodal and exopodal setae slender and plumose. Armature formula of all swimming legs as in Table 1.

Leg 1(Fig. 2A, 5A): Coxa with inner seta and transverse row of 6 spinules on distal outer margin. Basis with inner row of short setae and long slender basipodal seta, reaching middle margin of second endopodal segment, row of hair-like setules along inner margin, row of 5 spines adjacent to insertion of endopodal ramus. Endopod slightly shorter than exopodite. Apical spine of second endopodal segment strong, slightly longer than segment, with spinules at insertion point.

Leg 2 (Fig. 2B): Coxa with inner seta . Basis with short slender seta on outer margin. Surface of coxa and basis smooth. Endopod slightly shorter than exopodite.

Leg 3 (Fig. 2C): Coxa with inner seta. Basis with outer seta. Surface of coxa and basis naked. Exopodite slightly longer than endopod.

Leg 4 (Figs. 2D, 5B): Coxa and basis as in legs 2-3. Endopod shorter than exopodite. Second endopod about two times longer than wide (1.9), with apical spine shorter than bearing segment ( 0.8 times as long as segment). Spinules at insertion of all elements of second endopodal segment. Second exopodal segment with 2 outer spines and 1 apical spine with small spinules at insertion point.

Leg 5 (Figs. 1B, 2E, 5C): Basal segment completely fused to somite, dorsal seta stout and plumose, about 1.4 times longer than outer seta of free segment. Free segment subrectangular, 1.2 times longer than wide, inner spine slightly shorter than bearing segment. Outer seta about 4 times longer than inner spine. Inner spine strong and smooth; outer seta plumose on distal half.

Leg 6 (Figs 1B, 5D): Represented by small, low plate near lateral margin of genital double somite. Leg armed with relatively long plumose seta, and with 2 short, subequal smooth spines.

Male: Length of allotype $0.58 \mathrm{~mm}$ (excluding caudal ramus) (range $=0.58-0.64$ $\mathrm{mm}$; mean $=0.61 \mathrm{~mm} ; \mathrm{n}=2$ ). Body slender than in female, cephalothorax relatively long, slightly expanded laterally at midlength of cephalosome in dorsal view; lateral margins of pedigers 3 and 4 straight, produced posteriorly. Cephalothorax length= $0.40 \mathrm{~mm}$, representing $68 \%$ of total body length, dorsal surface smooth. Posterior margins of genital somite, free urosomites, and anal somite smooth ventrally (Fig. 3D) and dorsally. Ventral surface of anal somite smooth; distal ventral margin with rows of 13-15 spines at insertion point of caudal rami. Anal operculum (Fig 3G) slightly rounded, smooth.

Caudal ramus (Fig. 3D): Length of ramus $0.07 \mathrm{~mm}$. Length/width ratio $=3.1-$ 3.2. Inner and outer margins smooth, unornamented. Lateral apical seta (II) inserted al $52.3 \%$ of total length of caudal ramus. Outermost terminal (III) seta with small spinules at insertion and 0.7-0.8 times as long as caudal ramus. Dorsal seta (VII) longer than in females; about 0.7 times as long as caudal ramus. Innermost terminal seta (VI) 0.5 times as long as caudal ramus and. Innermost terminal seta (III) slightly shorter than outermost terminal seta (VI), III/VI ratio 0.78-0.9. All terminal caudal setae plumose. 


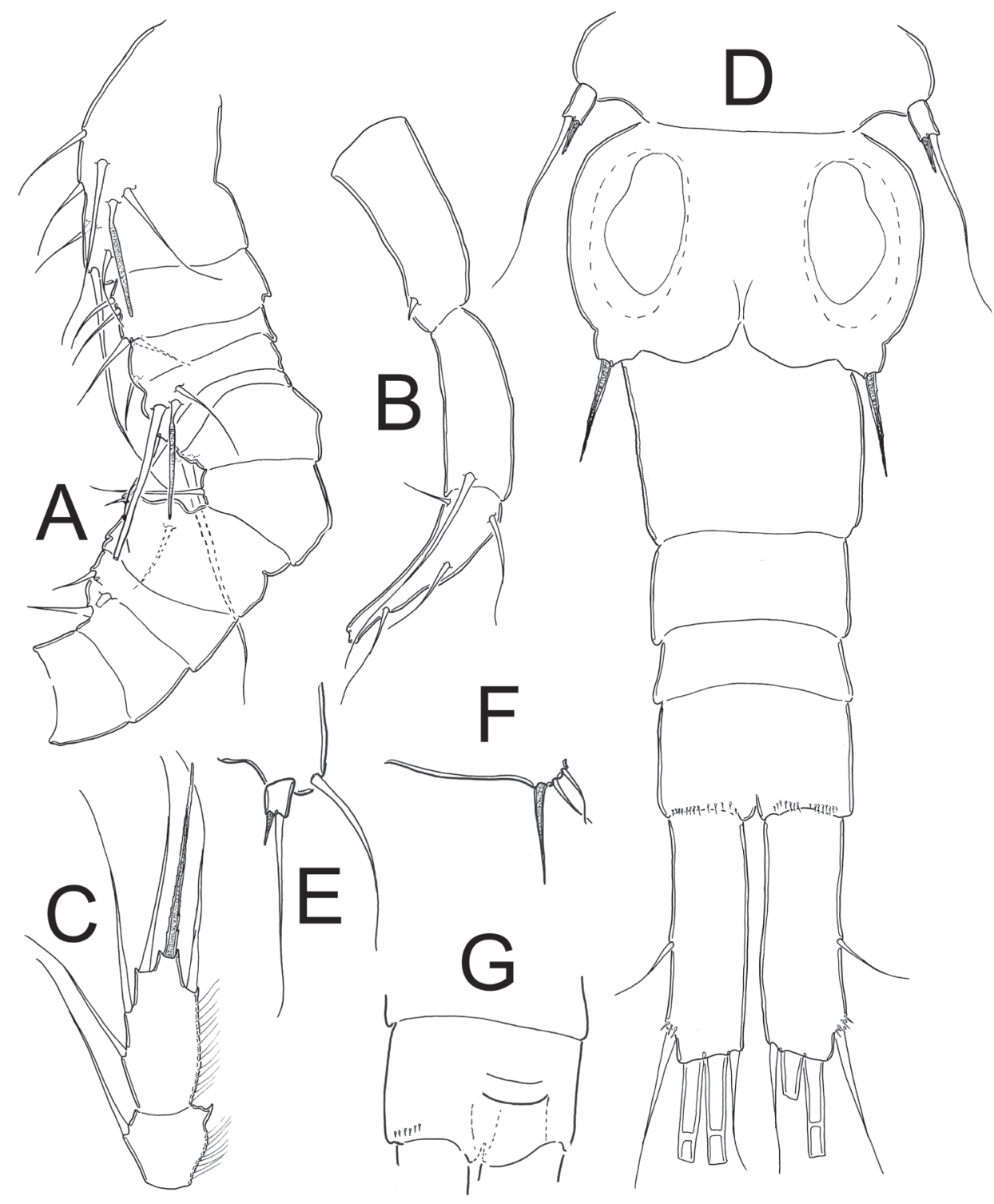

Figure 3. Metacyclops deserticus sp. n., male allotype from Coahuila, Mexico. A antennule (segments 1-11) B antennule (segments 12-14) C Endopod P4 D urosome E Leg 5 F Leg 6 G Anal operculum. Scales bars $\mathbf{A}-\mathbf{G}=50 \mu \mathrm{m}$.

Antennule (Fig. 3A-B): 14-segmented, geniculate, armature of segments 12, 13 and 14 not seen clearly (they could have more setae). Armature per segment as follows $(s=s e t a ; s p=$ spine ae= aesthetasc): $1(7 \mathrm{~s}+1 \mathrm{ae}), 2(4 \mathrm{~s}), 3(1 \mathrm{~s}), 4(2 \mathrm{~s}+1 \mathrm{ae}), 5(1 \mathrm{~s}), 6(1 \mathrm{~s})$, 7(1s), 8(1s+1sp), 9(2s), 10(1sp), 11(0), 12(1sp), 13(1s), 14(4s). 
Table I. Armature of swimming legs 1-4 (spines in Roman numerals, setae in Arabic) of Metacyclops deserticus sp. n. Sequence follows external to internal positions.

\begin{tabular}{c|c|c|c|c}
\hline & coxa & basis & endopodite & exopodite \\
\hline $\operatorname{leg} 1$ & $0-1$ & $1-1$ & $0-1 ; 1-\mathrm{I}-4$ & $\mathrm{I}-1 ; \mathrm{III}-5$ \\
\hline $\operatorname{leg} 2$ & $0-1$ & $1-0$ & $0-1 ; 1-\mathrm{I}-5$ & $\mathrm{I}-1 ; \mathrm{IV}-5$ \\
\hline $\operatorname{leg} 3$ & $0-1$ & $1-0$ & $0-1 ; 1-\mathrm{I}-5$ & $\mathrm{I}-1 ; \mathrm{IV}-5$ \\
\hline $\operatorname{leg} 4$ & $0-1$ & $1-0$ & $0-1 ; 1-\mathrm{I}-3$ & $\mathrm{I}-1 ; \mathrm{III}-5$ \\
\hline
\end{tabular}

Antenna, mouthparts and legs $1-3$ as in female.

Leg 4 (Fig. 3C): as in female except for relatively longer exopodite.

Leg 5 (Fig. 3E): Basal segment completely fused to somite, dorsal seta stout, as long as outer seta of free segment. Free segment subrectangular, 1.5 times longer than wide, spine as long as segment, outer seta about 5 times longer than inner spine. Inner spine strong, smooth; outer seta plumose on distal half.

Leg 6 (Fig. 3F): Represented by small, low plate near lateral margin of genital somite with relatively strong and long inner spine, two outer setae about the half of length of inner spine. Spine and setae smooth.

Remarks. The only two other species of the genus known to occur in North America, M. cushae Reid, 1991 and M. gracilis (Lilljeborg, 1853), are easily distinguishable from the new species. The former species belongs to the "Group C" (Karanovic 2004a, 2004b), with a 3433 spinal formula, being the only species in the group. Metacyclops gracilis belongs, like the new species, to Karanovic's (2004a, 2004b) "Group A". The new species differs from $M$. gracilis mainly by its having of one apical spine on the second endopodal segment of leg 4, instead of two such spines present in M. gracilis.

Following the comprehensive key to the known species of Metacyclops (Herbst 1988), the new species was tentatively identified as M. lusitanus Lindberg, 1961 from Portugal because both share several characters including: 1) 11-segmented female antennules, 2) margins of all somites smooth, 3) one spine on the apical margin of the second endopodal segment of leg 4, 4) inner apical seta of caudal ramus shorter than the outer seta, 5) length/width proportion of caudal ramus (about. 4.0), 6) apical seta of fifth leg 4 times longer than the apical spine, and 7) apical spine of the second endopodal segment of leg 4 shorter than the segment. However, a closer examination showed several differences between these two species. In M. lusitanus the dorsal caudal seta (VII)/outermost terminal seta (III) length ratio (0.7) differs from that found in the new species (0.8). In addition, the length ratio of the outermost terminal seta(III)/ innermost terminal seta (VI) of the caudal ramus differs between these species, in $M$. lusitanus it is 1.7 vs. 1.1 in the Mexican species. The length ratio of the basipodal seta/ total length of endopod of leg 1 slightly differs in these species, this ratio being 0.9 in the M. lusitanus and 0.85 in the new species. Also, the apical spine of the second endopodal segment of leg 1 is clearly stronger in $M$. deserticus sp. n. than it is in M. lusitanus (see Lindberg, 1961, fig. 1b). Metacyclops deserticus sp. n. has 6-8 small spinules at the insertion of the apical spine whereas such ornamentation is absent in M. lusitanus. 


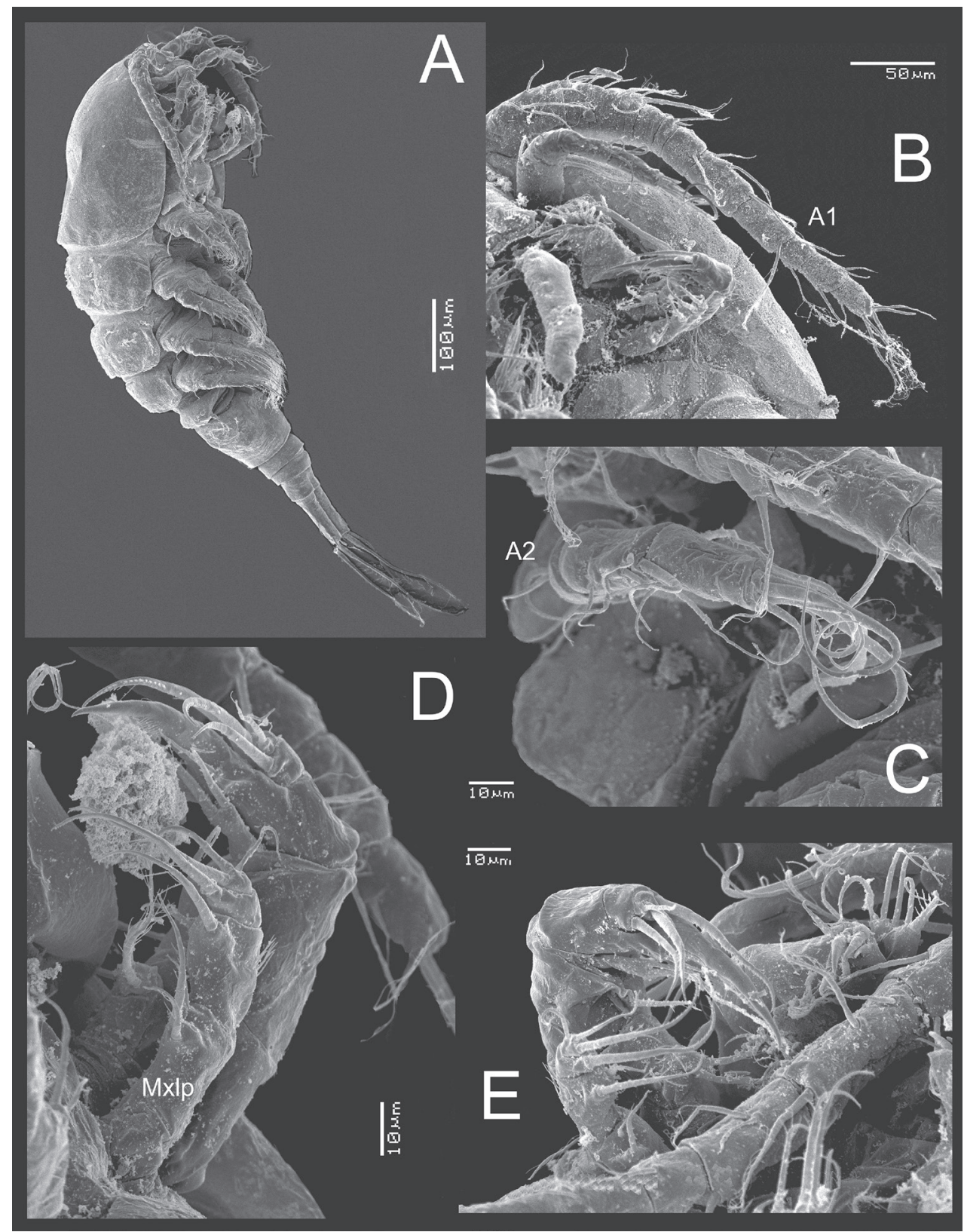

Figure 4. Metacyclops deserticus sp. n., SEM-processed female from Coahuila, Mexico. A habitus, lateral view $\mathbf{B}$ antennule $\mathbf{C}$ antenna $\mathbf{D}$ maxilliped (lateral view) $\mathbf{E}$ mouthparts.

We also followed Reid's (1987) key to the American species. Our specimens key down to $M$. curtispinosus Dussart, 1984. The new species shares several characters with $M$. curtispinosus, including 11-segmented antennules, also present in $M$. agnitus Herbst, 1988, M. pectiniatus Shen and Tai, 1964, M. subdolus Pesce, 1978, M. hannensis 
Defaye, 1992, and M. gasparoi Stoch, 1987. All of them belong to Karanovic's (2004a, 2004b) "Group A". The new species shares with M. curtispinosus, $M$ agnitus, $M$. pectiniatus, M. subdolus, and $M$. hannensis the presence of an exopodal seta on antennal basis, clearly differing from $M$. gasparoi -which lacks the exopodal seta. The naked antennal basis of Metacyclops deserticus sp. n. is shared by $M$. curtispinosus, $M$ agnitus, $M$. pectiniatus, and $M$. subdolus but $M$. hannensis bears a proximal row of spinules on the inner margin of the antennal basis.

Additional differences of the new species with respect to the American congeners include the length of the apical spine of the second endopodal segment of leg $1 /$ length of segment ratio (1.2), vs. about 0.7 in M. curtispinosus and M. agnitus and about 0.9 in M. subdolus, M. hannensis, and M. gasparoi. In M. deserticus sp. n., M. curtispinosus, M. subdolus, and M. gasparoi, the length of the basipodal seta of leg 1 exceeds the medial margin of the second endopodal segment of leg, whereas in $M$. hannensis it exceeds the total length of the endopodite and in M. agnitus it is absent. All these species have naked coxal sclerites of legs $1-4$.

The new species shares a similar length/width ratio of the second endopodal segment of leg4 with $M$. curtispinosus, $M$. agnitus, $M$. pectiniatus, and M. subdolus (range= 1.9-2.1), thus differing from the range reported for $M$. hannensis (1.6-1.7), and $M$. gasparoi (3.3). There are additional differences in the length ratio of the apical spine of leg 4 second endopodal segment/length of segment; $M$. deserticus sp. $\mathrm{n}$. shares with $M$. curtispinosus (a value of about 0.7 ) whereas this value is different in M. pectiniatus, M. subdolus and M. hannensis (0.9), M. agnitus (1.1) and M. gasparoi (1.4). The length ratio of external seta of leg 4 second endopodal segment/length of apical spine, is about 0.8 in $M$. deserticus sp. n. and M. curtispinosus, thus differing from M. gasparoi and M. hannensis (0.9-1.1), M. subdolus M. pectiniatus and $M$. agnitus (1.2-1.3). An additional difference between these species is the shape of the inner margin of the leg 4 basis. In the new species but also in M. curtispinosus, $M$. agnitus, $M$. pectiniatus, and $M$. hannensis it is rounded vs. triangular- in M. subdolus and M. gasparoi.

In addition, the new species differs from its congeners in the length of the external seta of free segment of $\mathrm{P} 5 /$ inner spine length ratio; in the new species, this ratio is 4.0, whereas it ranges between 2.9 and 3.1 in M. subdolus and between 5.0 and 5.7 in M. hannensis, M. pectiniatus and M. agnitus. In M. gasparoi this value is 6.6 and in $M$. curtispinosus it is about 8.0. The proportion between inner spine/length of segment of P5 is a character that also differs among these species. In M. curtispinosus the ratio is 0.3 , in the new species it is about 0.8 , in $M$. hannensis and $M$. agnitus the spine is as long as the segment, in M. pectiniatus and M. gasparoi it is about 1.3, in M. subdolus 1.5 times. Also the length proportion of the seta of fifth leg fused to the segment/outer seta of free segment represents a character that differs between species, in M. gasparoi it is $0.6, M$. hannensis and M. subdolus have a proportion ranging between 0.8 and 0.9 . M. agnitus and $M$. curtispinosus shares similar values (1.1-1.2) and both $M$. pectiniatus and the new species have a length ratio close to 1.4 (Herbst 1988, Pesce 1985, Lim and Fernando 1985, Pesce 1978, Defaye 1992, Stoch, 1987). 


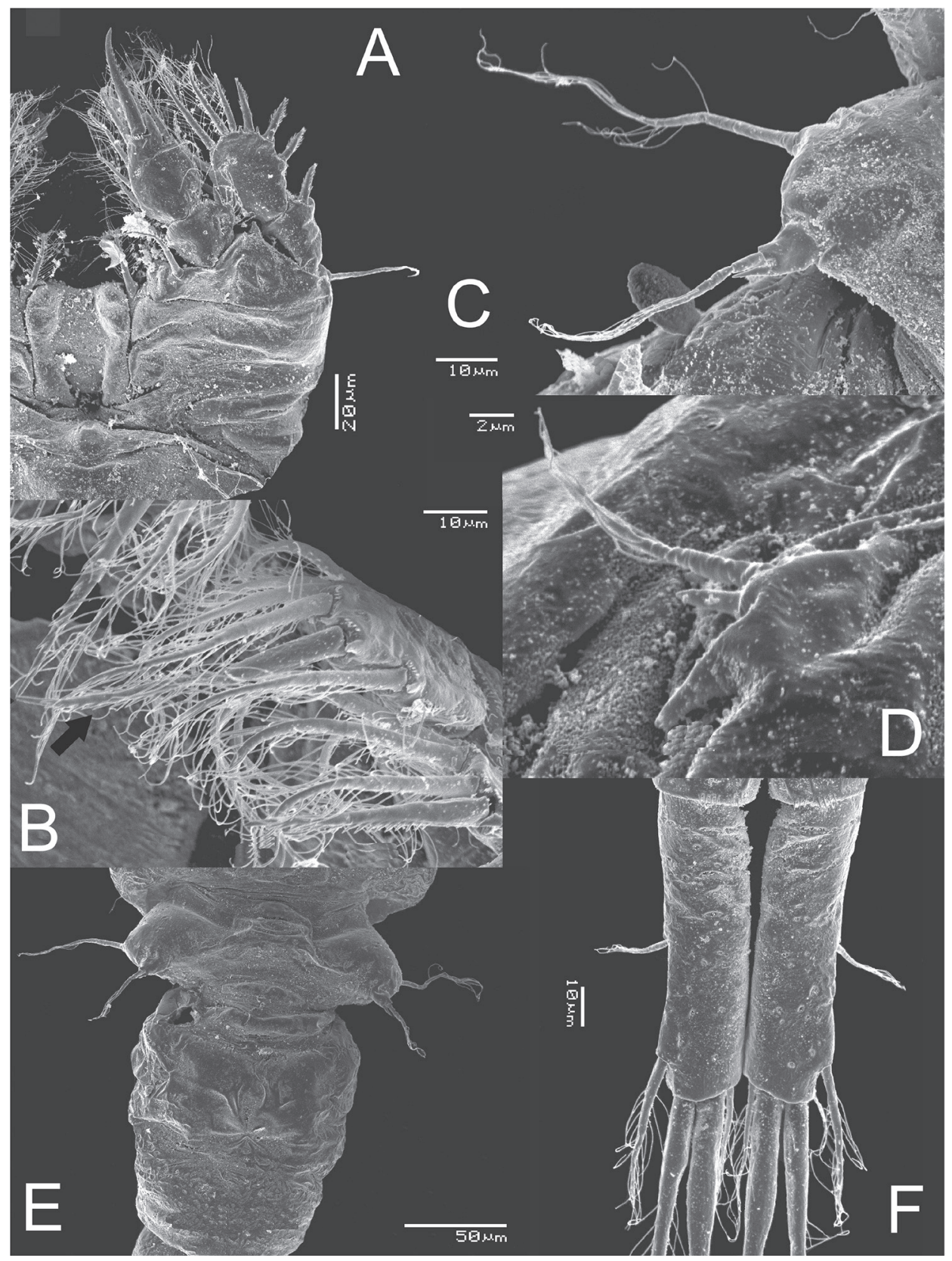

Figure 5. Metacyclops deserticus sp. n., SEM-processed female from Coahuila, México. A leg 1 B endopodite 2 leg $4 \mathbf{C}$ leg 5 D leg $6 \mathbf{E}$ genital double somite, ventral view $\mathbf{F}$ caudal ramus, ventral.

The length/width ratio of the caudal ramus also differs among these species, $M$. curtispinosus has relatively low value (2.4-2.8) that differs from those in M. agnitus, $M$. pectiniatus, and M. hannensis (3.2-3.4). Metacyclops subdolus has a wide range of variation 
(2.9-3.4). The new species has a relatively longer caudal ramus (3.5-3.8), but it is shorter than in $M$. gasparoi (5.5-5.7). Another valuable character is the length ratio of innermost terminal seta/outermost terminal seta; we found two main groups for this character. In the first one the innermost terminal seta is shorter than the outermost terminal seta; this character is present in $M$. agnitus (0.5), $M$. pectiniatus (0.6), $M$. hannensis (0.7), and in the new species (0.8). In the second group the innermost terminal seta is longer than outermost terminal seta: M. curtispinosus (1.2), M. subdolus (1.5-1.7), and M. gasparoi (2.0). In addition, the length dorsal seta/length of caudal ramus ratio also separates two groups. In the first group, the dorsal seta is shorter than the ramus: $M$. deserticus sp. $\mathrm{n}$. (0.4-0.5), M. curtispinosus and $M$. hannensis (0.7). In the second group the dorsal seta is longer than caudal ramus like in M. gasparoi, M. agnitus (1.1), and M. subdolus (1.8-2.1).

\section{Discussion}

Metacyclops deserticus sp. n. from northern central Mexico represents the first new species of the genus Metacyclops described in this country and is also the third record for North America (Reid 1991, Reid and Williamson 2010). There is a previous record of M. cushae by Gutiérrez-Aguirre and Cervantes-Martínez (2013) from southeast Mexico (Chiapas State). Most of the known American species of Metacyclops occur in tropical environments of the Neotropical region, mainly in South America and only $M$. cushae and M. gracilis have been reported from the Neartic region (Dussart and Defaye 2006). All previous records of species of Metacyclops in the Americas are from tropical environments; the North American records are from marshes in Louisiana and the Everglades in Florida (Bruno et al. 2005, Reid 1991). The finding of this species from an arid environment in Mexico represents the first continental record of the genus from this kind of habitat (Dussart and Defaye 2006, Rocha 1994). Members of Metacyclops have been recorded from arid environments in other regions of the world like Australia, New Zealand and Africa; some of these species inhabit epigean systems but others are known from subterranean waters (Dussart 1977, Dumont 1981, Defaye 1992, Pesce et al. 1996, Karanovic 2004a, 2004b). According to Defaye (1992) species of Metacyclops usually inhabit small pools, wells and ponds rich in vegetation and organic material, and their presumed tolerance to high temperatures and salinities appear to predict a wider distribution in Africa and other places with arid conditions, now including the American desert systems.

The arid areas of north-central Mexico were formed between the Late Oligocene and Middle Miocene (30-20 MYA), and were part of a general trend toward a greater aridity resulting from climate changes associated to the intense volcanic activity and tectonics that characterized the Cenozoic. The Rocky Mountains, the Mexican and Central-American Plateaus, and the sierras Madre were formed as result of tectonic activity during Cenozoic. The formation of the Sierra Madre Occidental and Sierra Madre Oriental during the Eocene and continuing until the middle Miocene provided 
a new barrier to the atmospheric flow. This barrier blocked the masses of warm, moist air from the Pacific Ocean and the Gulf of Mexico and caused a severe drought and desertification of the Mexican Plateau. The Mexican Plateau includes the states of Coahuila, Chihuahua, Zacatecas, Durango. The Miocene climate change segregated the species along latitudinal and longitudinal gradients, thus favoring radiation processes of some lineages (Devitt 2006). It has been suggested that some of these areas of Northern Mexico functioned as refugia during the Pleistocene glaciations, thus favoring local process of isolation-speciation of the aquatic biota (Bănărescu 1991, SuárezMorales et al. 2010, Mercado-Salas et al. 2012).

The cyclopoid copepod fauna of arid areas of central-north of Mexico (Chihuahuan Desert) is currently represented by 39 species belonging to 12 genera. This binational zone is currently deemed as an area with a high endemicity; up to $20 \%$ of these species are endemic to these arid areas (Mercado-Salas et al. 2006, 2009, Mercado-Salas and Suárez-Morales 2009, 2011, Suárez-Morales and Walsh 2009, Suárez-Morales et al. 2010). The new species of Metacyclops appears to be endemic to the Chihuahuan Desert, thus incrementing the importance of this and other arid systems as refuges of an undescribed diversity that certainly deserves further study. Most interestingly, the type locality harbors at least three endemic crustacean species, the copepod $M$. deserticus and the large branchiopods anostraceans (fairy shrimps) Branchinecta oterosanvicentei Obregón-Barboza, Maeda-Martínez, García-Velazco and Dumont, 2002, and Streptocephalus guzmani Maeda-Martínez, Belk, Obregón-Barboza and Dumont, 1995.

\section{Acknowledgments}

We gratefully acknowledge the support by Araceli Adabache, Laboratorio de Ecología, Universidad de Aguascalientes, for help and advice in the SEM processing and examination of the specimens. Also, we acknowledge the advice and comments by Dr. Janet W. Reid. A previous version of this contribution was greatly improved by constructive comments and suggestions from two anonymous reviewers. This work is part of the first author's (NM-S) Master of Sciences thesis developed at El Colegio de la Frontera Sur (ECOSUR) and was derived from a project supported by the Mexican Comision Nacional para el Conocimiento y Uso de la Biodiversidad (CONABIO-GT-034).

\section{References}

Bănărescu P (1991) Zoogeography of Fresh Waters: Volume 2: Distribution and dispersal of freshwater animals in North America and Eurasia. 1st ed. AULA-Verlag Wiesbaden, Germany, pp. 520-1091.

Brancelj A (1987) Cyclopoida and Calanoida (Crustacea, Copepoda) from the Postojna-Planina Cave System (Slovenia). Biološki Vestnik, Ljubljana 35:1-16. 
Bruno MC, Reid JW, Perry SA (2005) A list and identification key for the freshwater freeliving copepods of Florida (U.S.A.). Journal of Crustacean Biology 25(3): 384-400. doi: $10.1651 / \mathrm{C}-2538$

Davis JC (1979) A faunal survey of Ezell's Cave, Hays County, Texas. Master Thesis, San Marcos: Texas Southwest Texas University State.1-141 pp.

Defaye D (1992) Metacyclops hannensis sp. n. (Crustacea, Copepoda, Cyclopoïda), un cyclopide nouveau du Sénégal. Revue d' Hydrobiologie Tropicale 25(2):145-151.

Devitt TJ (2006) Phylogeography of the Western Lyresnake (Trimorphodon biscutatus): testing aridland biogeographical hypotheses across the Neartic-Neotropical transition. Molecular Ecology 15: 4387-4407. doi: 10.1111/j.1365-294X.2006.03015.x

Dodson SI, Silva-Briano M (1996) Crustacean zooplankton species richness and associations in reservoirs and ponds of Aguascalientes state, Mexico. Hydrobiologia 325: 163-172. doi: $10.1007 / \mathrm{BF} 00028277$

Dumont HJ (1981) On a collection of zooplankton from Somalia, with a description of three new species of Copepoda. Italian Journal of Zoology 7: 103-111.

Dussart BH (1977) Contribution a l'étude des Copépodes des eaux douces du Ruanda. Bulletin de lnstitute Fondamental d'Afrique Noire 4: 821-840.

Dussart BH (1984) Some Crustacea Copepoda from Venezuela. Hydrobiologia 113:25-67. doi: 10.1007/BF00026592

Dussart BH, Defaye D (2006) World Directory of Crustacea Copepoda. II. Cyclopiformes. Backhuys Publishers, Leiden 354 pp.

Fiers F (2001) Meridiecyclops gen. nov., a new cyclopoid genus (Crustacea: Copepoda: Cyclopidae) from southern Australia. Invertebrate Taxonomy 15:893-908. doi: 10.1071/ IT01003

Galassi DMP, Pesce GL (1994) Metacyclops geltrudae sp. n., a new Cyclopoid from Ground waters of Venezuela (Copepoda, Cyclopidae). Crustaceana 67(3): 284-287. doi: $10.1163 / 156854094 X 00387$

Gaviria S, Aranguren N (2007) Especies de vida libre de la subclase Copepoda (Arthropoda, Crustacea) en aguas continentales de Colombia. Biota Colombiana 8(1): 53-68.

Gutiérrez-Aguirre MA, Cervantes-Martínez A (2013) Diversity of freshwater copepods (Maxillopoda: Copepoda: Calanoida, Cyclopoida) from Chiapas, Mexico with a description of Mastigodiaptomus suarezmoralesi sp. n. Journal of Natural History. 47(5-12): 479-498.

Herbst HV (1988) Zwei neue Metacyclops (Crustacea: Copepoda) von den Westindischen Inseln Barbados und Aruba: M. agnitus sp. n. und M. mutates sp. n., sowie ein bestimmungsschlüssel für das genus. Bijdragen tot de Dierkunde 58(1):137-154.

Herbst HV (1990) Metacyclops janstocki sp. n. (Crustacea, Copepoda) von Antigua (Westindischen Inseln). Beaufortia 41: 75-81.

Herrick CL (1895) Synopsis of the Entomostraca of Minnesota. I. Copepoda of Minnesota. Geological and Natural History Survey of Minnesota, Zoological series 2:1-337.

Karanovic T (2004a) The genus Metacyclops Kiefer in Australia (Crustacea: Copepoda: Cyclopoida), with description of two new species. Records of the Western Australian Museum 22:193-212. 
Karanovic T (2004b) Subterranean copepods from arid Western Australia. Crustaceana Monographs 3: 68-100.

Karanovic T, Eberhard SM, Murdoch A (2011) A cladistic analysis and taxonomic revision of Australian Metacyclops and Goniocyclops, with description of four new species and three new genera (Copepoda, Cyclopoida). Crustaceana 84(1): 1-67. doi: $10.1163 / 001121610 \times 546698$

Lilljeborg W (1853) Om de inom Skäne förekommande Crustaceer ordningarde Cladocera, Ostracoda och Copepoda. Des crustaceis ex orsinibus tribus: Cladocera, Ostracoda et Copepoda, in Scania occurrentibus: i-xvi, 1-222, pls. I-XXVII (Berling, Lund).

Lim RP, Fernando CH (1985) A review of Malaysian freshwater Copepoda with notes on new records and little know species. Hydrobiologia 128:71-89. doi: 10.1007/BF00008942

Lindberg K (1961) Remarques sur le genre Metacyclops (Kiefer, 1927) et description d'un Metacyclops nouveau du Portugal. Kungl, Fysiografiska Sällskapets I Lund Förhandlingar 31(14): 133-145.

Maeda-Martínez AM, Belk D, Obregón-Barboza H, Dumont HJ (1995) Diagnosis and phylogeny of the New World Streptocephalidae (Branchiopoda: Anostraca). Hydrobiologia 298:15-44. doi: 10.1007/BF00033798

Mercado-Salas NF, Suárez-Morales E (2009) A new species and illustrated records of Paracyclops Claus, 1893 (Copepoda: Cyclopoida) from Mexico. Journal of Natural History 43(45-46): 2789-2808. doi: 10.1080/00222930903108462

Mercado-Salas NF, Suárez-Morales E (2011) Morfología, diversidad y distribución de los Cyclopoida (Copepoda) de zonas áridas del centro-norte de México. I. Cyclopinae. Hidrobiológica 21: 1-25.

Mercado-Salas NF, Suárez-Morales E, Silva-Briano M (2006) A new Acanthocyclops Kiefer 1927 (Copepoda, Cyclopoida) from Central Mexico with comments on the distribution of the genus in Middle America. International Review of Hydrobiology 91: 148-163. doi: 10.1002/iroh.200510856

Mercado-Salas NF, Suárez-Morales E, Silva-Briano M (2009) Two new Acanthocyclops Kiefer, 1927 (Copepoda: Cyclopoida: Cyclopinae) with pilose caudal rami from semiarid areas of Mexico. Zoological Studies 48: 380-393.

Mercado-Salas NF, Pozo C, Morrone JJ, Suárez-Morales E (2012) Distribution patterns of the American species of the Freshwater genus Eucyclops (Copepoda: Cyclopoida). Journal of Crustacean Biology 32(3): 457-464. doi: 10.1163/193724012X626502

Obregón-Barboza H, Maeda-Martínez AM, García-Velazco H, Dumont HJ (2002) Branchinecta oterosanvicentei sp. n. (Branchiopoda: Anostraca), a new fairy shrimp from the Chihuahuan desert, with a proposal for the conservation of the Brachinectidae of Mexico. Hydrobiologia 467(1-3): 45-56. doi: 10.1023/A:1014924311329

Pesce GL (1978) The occurrence of Metacyclops subdolus Kiefer (Crustacea: Copepoda) in subterranean waters of Greece with remarks on its systematic status. International Journal of Speleology 10:179-183. doi: 10.5038/1827-806X.10.2.4

Pesce GL (1985) Cyclopoids (Crustacea, Copepoda) from west Indian groundwater habitats. Bijdragen tot de Dierkunde 55(2): 295-323. 
Pesce GL, De Laurentiis P, Humphreys WF (1996) Copepods from ground waters of Western Australia, I. The genera Metacyclops, Mesocyclops, Microcyclops and Apocyclops (Crustacea: Copepoda: Cyclopidae). Records of the Western Australian Museum 18:67-76.

Reid JW (1987) The cyclopoid copepods of a wet campo marsh in Central Brazil Hydrobiologia 153:121-138.

Reid JW (1991) The genus Metacyclops (Copepoda: Cyclopoida) present in North America: $M$. cushae new species from Louisiana. Journal of Crustacean Biology 11 (4): 639-646. doi: $10.2307 / 1548532$

Reid JW, Williamson CE (2010) Copepoda. In: Thorpe JH, Covich AP (Eds) Ecology and Classification of North American Freshwater Invertebrates. Academic Press, New York, 829-899. doi: 10.1016/B978-0-12-374855-3.00021-2

Rocha CEF (1994) New species of Metacyclops (Copepoda, Cyclopidae) from Brazil, with remarks on $M$. campestris. Zoologica Scripta 23(2):133-146. doi: 10.1111/j.14636409.1994.tb00380.x

Stoch F (1987) Cave-dwelling cyclopoids (Crustacea, Copepoda) from Venezia Giulia (Northeastern Italy). Bulletin Zoölogisch Museum 11(5): 42-55.

Suárez-Morales E, Avilés S, Da Rocha CEF (2002) Extensión del ámbito geográfico de dos copépodos haliciclópinos (Copepoda: Cyclopoida: Halicyclopinae) en el sureste de México. Anales del Instituto de Biología, Universidad Nacional Autónoma de México, serie Zoología 73(1):113-115.

Suárez-Morales E, Gutiérrez-Aguirre ME, Walsh E (2010) First checklist of freshwater Copepoda (Crustacea) from the Chihuahuan Desert, with comments on biogeography. The Southwestern Naturalist 55(4): 525-531. doi: 10.1894/JC-35.1

Suárez-Morales E, Reid JW (1998) An updated list of free-living freshwater copepods (Crustacea) of México. The Southwestern Naturalist 43(2): 256-265.

Suárez-Morales E, Walsh E (2009) Two new species of Eucyclops Claus (Copepoda: Cyclopoida) from the Chihuahuan Desert with a redescription of E. pseudoensifer Dussart. Zootaxa 2206: 1-16.

Wilson CB (1932) The copepod crustaceans of Chesapeake Bay. Proceedings of the United States National Museum 80(15): 1-54. doi: 10.5479/si.00963801.80-2915.1 